\title{
Reviews
}

\section{Enrique Alcaraz Varó. El inglés juridico. Barcelona: Ariel, 1994, xi + 291 pp.}

En una reseña anterior, hace ahora exactamente un año, teníamos el placer de recibir el Diccionario de términos jurídicos inglés-español de los doctores Enrique Alcaraz y Brian Hughes. Apenas hemos podido recuperarnos de la agradable sorpresa que dentro del campo de la traducción suponía aquella obra, nos encontramos ahora con esta aproximación detallada y exhaustiva al inglés jurídico, resultado sin duda del mismo esfuerzo investigador.

Como acertadamente señala el autor, el inglés jurídico, a caballo entre el derecho y la filología, no ha recibido en España la atención que merece, a pesar de que en la actualidad estamos a punto de adoptar instituciones como el jurado, de gran prestigio en el ámbito de los paises de habla inglesa; por contra, en el mundo anglosajón los lingüistas y los juristas sí han unido sus esfuerzos en el estudio de la expresión jurídica. Tal es así debido a la especial naturaleza del derecho inglés que, al basarse primordialmente en la jurisprudencia, otorga gran importancia al significado de los textos, tanto por lo que respecta a la interpretation (sentido estricto de las palabras) como a la construction (ámbito de aplicación y repercusiones de cada sentencia).

Podemos observar la voluntad didáctica del autor en la organización de la obra, que sigue una marcada estructura en pirámide invertida, pasando de lo general a lo particular. Así, el primer capítulo permite al filólogo o al traductor introducirse paulatinamente en el mundo del derecho inglés de forma general, con especial mención de sus dos fuentes principales, el statute law, conocido como derecho estatutario o legislado, y el common law, o derecho consuetudinario, basado en el precedente, éste con menor implantación en el derecho español y francés. Precisamente es este último elemento el que ofrece especial interés para los lingüistas, dado que en las sentencias creadoras de precedente existe un apartado en el que el juez, mediante la ratio decidendi, expone los argumentos que fundamentan el fallo, y la aplicación posterior de tal sentencia como precedente dependerá en gran medida de la interpretación que se haga de estos argumentos.

A continuación, el profesor Alcaraz dedica tres capítulos a la organización general de la justicia inglesa, así como al procedimiento civil y al penal, en los que la prosa aparece salpicada de abundantes notas entre paréntesis que, acertadamente en nuestra opinión, permiten ir conociendo el vocabulario al tiempo que los conceptos que designa, como en este fragmento que citamos:

El Derecho penal (criminal law) entiende de los delitos y de las penas; en este sentido, se puede afirmar que su finalidad es sentar las bases para que pueda aprehender (apprehend), procesar (prosecute), juzgar (try) y condenar (convict), tras dictar la sentencia (sentence) correspondiente, a quienes infringen (violate) las normas básicas 
(basic rules) de la convivencia social (group existence). De esta manera, la justicia penal (criminal justice), aparte de disuadir (deter) a posibles transgresores de la ley (lawbreakers), ofrece la posibilidad de convertir a los delincuentes en ciudadanos cumplidores de la misma (law-abiding citizens). (35)

En estos capítulos, fundamentales para entender el sistema judicial inglés, se ofrece un análisis completo de todas las instancias responsables de los procedimientos, según se trate de casos civiles y penales, para lo cual resulta de inestimable valor aclaratorio el cuadro de la página 17, así como las frecuentes notas a pie de página en las que se aclara la diferencia entre dictar sentencia en lo civil (give judgment) y en lo penal (pass sentence); también se nos antoja imprescindible el estudio de las secciones del High Court of Justice, en el que se detallan todos los tipos de procesos de los que entiende cada uno.

El autor ofrece una interesantísima visión comparativa del inglés y el español jurídicos, no ya solamente desde el punto de vista estilístico, sino incluso en cuanto a posibles repercusiones interpretativas. Como ejemplo, se cita el problema de la traducción del present perfect inglés, que en el caso de una vinculación contractual puede suponer que un compromiso siga vigente o se considere finalizado: si un demandante afirma "I have been your representative for ten years," está declarando que se considera todavía vinculado a la empresa, mientras que una traducción errónea, como "He sido su representante durante diez años," puede darnos a entender que la persona contempla ese período como finalizado.

En los capítulos siguientes (VI-XVIII) el libro está organizado siguiendo los contenidos de los textos jurídicos ingleses, desde los distintos tipos de contratos a las cuestiones de representación procesal, pasando por los testamentos, los divorcios y el arbitraje. En cada capítulo se aborda el tema mediante una detallada introducción, que presenta las peculiaridades del derecho inglés, de nuevo con los paréntesis que citábamos más arriba cada vez que aparece un concepto relevante. A continuación aparecen los textos, que se acompañan de extensas notas a pie de página, que frecuentemente superan en longitud el texto mismo. En este apartado es donde aflora el profundo conocimiento del autor del español jurídico, pues la dificultad de traducción de este tipo de registro no estriba en los términos aislados, que nos podría ofrecer un mero glosario, sino en las fórmulas, las que verdaderamente "dan color" a los textos jurídicos en cualquier idioma. Tal es así cuando se proponen las traducciones "los juicios se celebran a puerta cerrada" o "sus actuaciones constan en un acta" para las fórmulas inglesas "courts sit in camera or in chambers" y "proceedings are maintained and recorded"; no basta, en efecto, con proponer una traducción que facilite la comprensión, sino que se trata de aportar la versión equivalente y de uso común de cada expresión en cada lengua, tal y como exige un registro tan codificado como el jurídico, en el que los sinónimos apenas existen.

No dudamos de que los profesionales del derecho agradecerán la visión clara y comparativa de instituciones que carecen de equivalente en España, tales como el jurado, los magistrates legos o los tribunales de arbitraje, sobre todo teniendo en cuenta las ventajas que su implantación en nuestro país podría ofrecer a la hora de reducir la congestión de los juzgados; la reforma ya se está iniciando con los mal llamados en nuestra opinión "juicios rápidos," o sumarios por el procedimiento abreviado, cuyas pruebas en España han resultado satisfactorias tanto para los acusados como para la 
fiscalía, y que no son más que una adaptación de los summary trials ingleses y galeses. En estos procesos, que representan el noventa por ciento de los casos judiciales, el acusado evita gastos al erario público mediante la declaración de culpabilidad, que puede realizarse incluso por carta, y de este modo recibe una sentencia rápida y por lo general atenuada.

Más allá de los límites del derecho, se trata ésta de una obra de utilidad para gran número de profesionales. Como filólogos, en primer lugar, no podemos sino agradecer la excelente visión comparativa del lenguaje jurídico en inglés y en español, respaldada por sólidas bases lingüísticas; del mismo modo, entendemos que los estudios sobre civilización inglesa, de reciente incorporación en los nuevos planes de estudio de filología, han de tener como parte fundamental el análisis de las instituciones del derecho inglés, que en gran medida determinan la ideosincrasia británica. Los sociolingüistas, por su parte, encontrarán apasionante la especialización de la jerga de los jueces y abogados, que convierte el código utilizado en una manifestación de poder, que deja inermes a los que no pueden utilizarla ni entenderla, y que sin duda alguna podría dar lugar a estudios paralelos sobre cómo se establecen idénticas relaciones en castellano.

Miguel Ángel Campos Pardillos

Janet A. Kourani, James P. Sterba and Rosemarie Tong, eds. Feminist Philosophies. New York and London: Harvester-Wheatsheaf, 1992, IX + 406 pp.

Feminism or Feminisms? It is a difficult and intriguing question. Some people-probably mainly women and men committed to the project of gender equality - would answer feminisms. Not one but many. Other people, maybe less informed, would consider the question as uninteresting and answer vaguely: feminism. Just one. But what do we really mean when we speak or write on women and feminism? What do we mean when we question the construction of the normative feminine identity? Is it anachronistic to go on discussing these topics? Shall we have to yield to the temptation of falling into the trap of the theorists that have claimed the death of feminism and that have foreshadowed the arrival of the era of postfeminism?

Obviously, Feminist Philosophies does not contain the answers to these questions, but we think that it represents a useful and intelligent starting point to get closer to a better understanding of contemporary feminist theories. It can be a good, and extremely well structured, introduction to the expanding field of gender studies for all the people that have not had the chance to approach the subject or want to know more about it. At the same time, it is a good antology of some of the best essays written on the philosophy of feminism to keep at hand. In short, as the editor points out in the preface: "This antology is designed to be a basic course in feminist philosophy or a first course in women's studies" (ix).

The book is composed of a collection of 40 essays; it is divided into two parts, a Methodological Postscript and a bibliographical section with suggestions for further reading. Part I is divided into seven sections: Sex-Role Socialization, Sexuality, 
Reproduction, Self-Images, The World of Work, The Domestic Scene and Cultural Invisibility. The second part is composed of five sections: Liberal Feminism, Radical Feminism, Psychoanalitic Feminism, Marxist/Socialist Feminism and Postmodern Feminism. The contents of the book and its structure underline two main ideas. The first is to relate women as social subjects to our contemporary reality and the second is to present the main theoretical schools within the field of gender studies.

The normative sexual identity, the family, the work place or the construction of the feminine body are parts of the mosaic that make up the life of most women. The assigned essentialist identity that women have to suffer and all the problems related to the construction of this identity, materialize in a number of rules that they are expected to obey and accept in order to be considered as feminine. The dominant ontological discourse that construe the feminine normative self acts through a network of power relations that are located in multiple sites. Sexuality is one of these sites and, within this field, the control over reproduction—or the free access of women to legal abortion, for instance-is an argument that is strictly related to the question of women's right and to the right that every individual has to maintain control over his or her sexuality. This means that to lose control over one's sexuality is equal to losing power over an important part of your life.

Other prominent fields where power relations act powerfully are the work place -difference in wages and benefits, for example-or the "disciplinary practices" that many women undergo to shape their bodies according to a discourse that, depending on fashion or other historical and cultural factors, wants them different all the time. As Sandra Bartky points out in an essay included in this collection:

Styles of the female figure vary over time and across cultures: they reflect cultural obsessions and proccupations in ways that are still poorly understood. Today, massiveness, power, or abundance in a woman's body is met with distaste ... It is a silhouette that seems more appropriate to an adolescent boy or a newly pubescent girl than to an adult woman. Since ordinary women have normally quite different dimensions, they must of course diet. (105)

Literary history is another field where the contribution made by women along the centuries has very rarely been considered as important or relevant. But, according to the French philosopher Michel Foucault, within the relation power/knowledge writing can be considered as a mode of resistance and it is in this sense that some feminist theorists are committed to rediscovering and publishing works written by women and try to remedy the "cultural invisibility" that these texts-novels, poems, essays, short stories, etc.-had been condemned to in the last centuries.

As we have stressed before, the section Cultural Invisibility is the last of Part I and it acts as a bridge between the first and the second part of Feminist Philosophies. If the essays of Annette Kolodny, Joan Scott, Rosemary Radford Ruether and Sue Rosser stress the enormous importance that the feminine voice and the feminist perspective have in the cultural and religious field, in Part II of the book their call materializes in a number of essays that introduce the reader to a variety of feminist theories.

At the beginning of this review we were wondering if it is possible to talk of feminism as a unique and unitary concept or if, on the contrary, we have to consider feminism as a 
multiplicity where different points of views melt and if what they have in common is a political and social commitment not only to gender equality, but to the elimination of a politics of exclusion based on gender, race, social class or sexual orientation. We personally think that it is not possible, nowadays, to talk of just one feminism and the essays published in the second part of Feminist Philosphies sustain this point of view. They represent the variety of perspectives and the wide range of social and philosophical tendencies that exist within the field of gender studies. From the liberal feminists' ideas to the postmodern theorists; approaching the marxist perspective or getting closer to the radical feminists' point of view, the reader is introduced, in an easy and skilled way, into the complex and lively theoretical world of feminist theories.

As we have pointed out above, a certain understanding of sexuality, reproduction or the construction of the feminine body, among other things, can represent a way to limit the active participation of women in the social, cultural and economical sphere. In this context we think that the questioning of the normative ontological and epistemological categories that feminist intellectuals, men and women, are carrying on is of basic importance for the development of a fairer politics of gender equality. Their work relates women as marginalized social individuals to theories that can suggest solutions to overcome the politics of gender discrimination that exclude a great part of the feminine population from an active social and political role. In this sense, we think that the editors of Feminist Philosophies have been able to offer a good and professional summary example of this intellectual project.

Silvia Caporale Bizzini

\section{Gregory Comnes. The Ethics of Indeterminacy in the Novels of William Gaddis. Gainesville: UP of Florida, 1994, $188 \mathrm{pp}$.}

The interrelation between ethic and aesthetic judgment remains a missing point in many theoretical and critical studies on contemporary fiction. Why postmodern fiction is or is not innovative from the formal point of view has been thoroughly explained by many scholars, and the myriad devices that sustain what is usually referred to as "self-conscious fiction" have been already classified; but the importance of avant-garde experiments to our comprehension of reality has not been, in my view, carefully examined.

Gregory Comnes's study is a brilliant effort to fill this gap in the particular context of Gaddis's fiction. But his recent book on Gaddis is both necessary and useful for another reason. Besides partially filling this gap existing in the field of studies on the postmodern novel, it also provides an example of the ethical relevance of fiction to our understanding. Like Coover or Pynchon, Gaddis is one of those contemporary authors for whom the consideration of "relativism" is, or should be, a basic assumption when it comes to organizing and evaluating reality. The dismantling of what Lyotard calls "grand narratives" is one of his chief concerns, as it is of many other contemporary novelists-the relevant question in Gaddis's fiction being that the problematization of our comprehension of reality takes on its important ethical dimensions as well. Implied, in Gaddis's fiction as 
well as in Comnes's study, is the idea that relativism leads not to nihilism but to the disclosure of diversity and otherness as conditions of knowledge and judgment, and so "helps us construe sense and the possibility of order in a different way" (3). This is the basic working of ethics in the novels of Gaddis: the assumption of difference and the consideration of otherness. And this is achieved, according to Comnes, by means of two fundamental strategies: the calling into question of textual representation and the ensuing revitalization of the reader's role in the interpretive activity. The former is intended to undermine closure and the possibility of straightforward, unquestioned reference by undoing the alleged natural and objective character of representation. The latter, on the other hand, is intended to make the reader get involved in textual interpretation-so that meaning be not conceived of as the fixed product of outward reference but rather the outcome of an active process of interchange between author, text, and reader.

This is clearly a poststructuralist-hermeneutic approach, mostly based on Wolfgang Iser's and Stanley Fish's theories of reader-response criticism; but, although the relevance of postmodern theory in Gaddis's fiction, especially in The Recognitions, has been thoroughly explored recently (see Johnston), Comnes's study still contributes a new and fresh perspective in this regard. Drawing heavily on the thought of Walter Benjamin, he analyzes how the representation of "a world without absolutes" in Gaddis's fiction implies a constructive ethical commitment of the first kind. The key concept of the whole book is that of agap $\bar{e}$, which designates the attitude of "giving ... in the face of any situation" (30) that helps Gaddis's readers to apprehend and assess ethically the real world by unveiling the mythical residue of structures of knowledge and power. It is after reading Comnes's book that the vision of Gaddis's first three novels is not so much that of formally "postmodern" fictions but rather of broadly reflexive works-"epistemological novels," in Comnes's phrase-in which the examination of meaning figures prominently. Far from the moral reductiveness of critics such as John Gardner, Gaddis is illuminated by this work of criticism, in which literary and intellectual considerations are merged in order to offer an exhaustive assessment of Gaddis's fiction in light of poststructuralist developments in the field of ethics.

Unfortunately, Comnes's valuable book was in print when Gaddis's recent novel, entitled A Frolic of His Own, appeared. The only reference is a brief remark in the book's Conclusion referring to the continuity of Gaddis's interest in ethical issues, this time in the field of litigation. Like the others, Gaddis's new novel deserves study in detail because of its vigorous reflexive interests. Although Gaddis's exploration here seem to be confined to the field of law and order, its implications go far beyond-into the realm of what it means "refusing to think in terms of evidence" (Gaddis 110).

Regardless of this small problem, Comnes's work deserves a distinguished place in the field of criticism on contemporary fiction. It combines theoretical sophistication and critical lucidity, and the result is one of the most comprehensive and perceptive works on William Gaddis's fiction. 


\section{Other Works Cited}

Gaddis, William. A Frolic of His Own. New York: Poseidon P, 1994.

Johnston, John. Carnival of Repetition: William Gaddis's The Recognitions and Postmodern Theory. Philadelphia: U of Pennsylvania P, 1990.

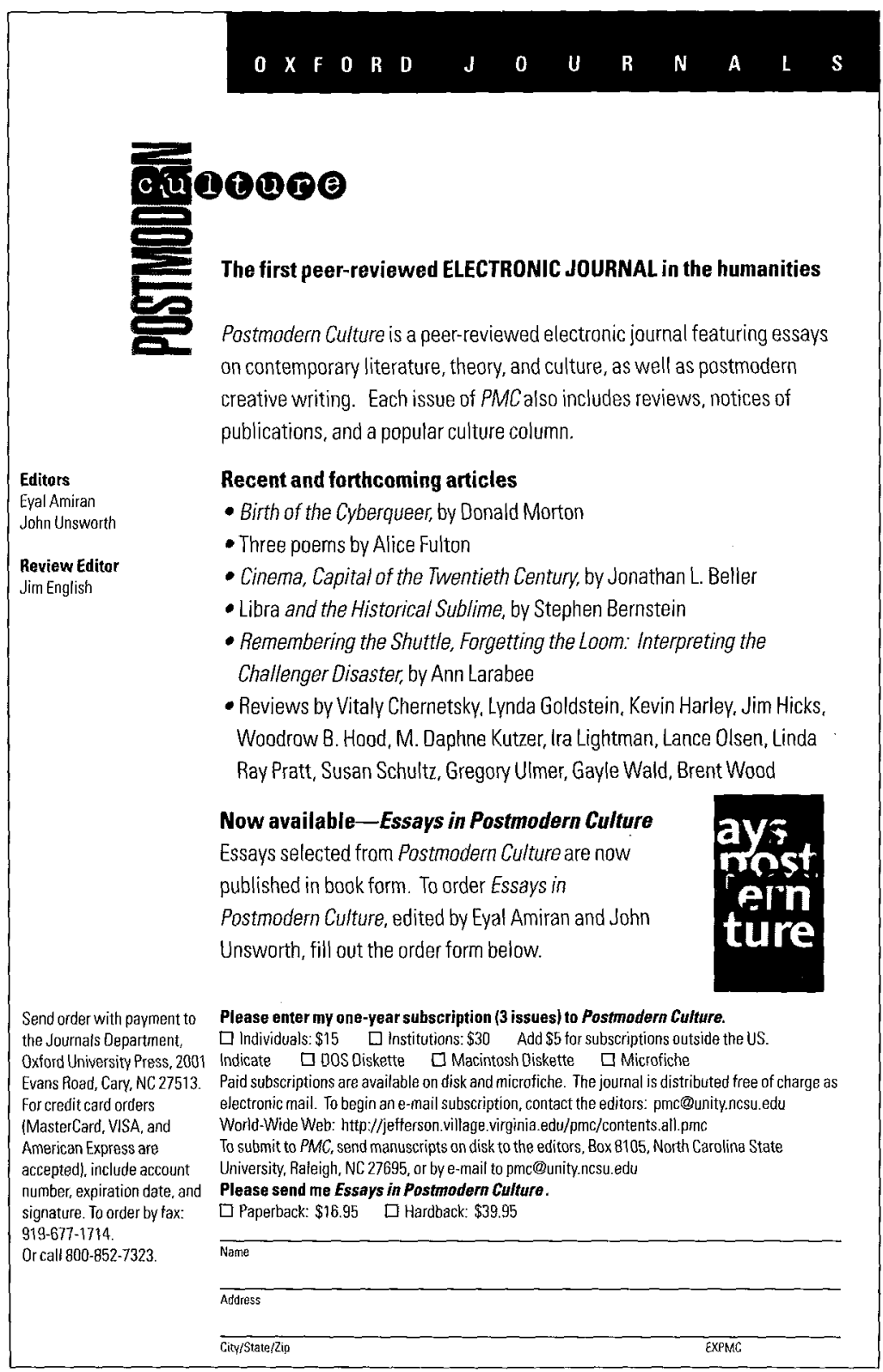




\section{Recommended Books}

The Editors mention here some recent valuable books within the field of English studies, or fields closely related to it, that are thought worthy of particular attention:

It is a pleasure to present here a new title of the series Letras Universales published in Spain by Cátedra. It is the edition and translation into Spanish of Bram Stoker's Dracula, prepared by Juan Antonio Molina Fox (Madrid: Cátedra, 1993), 630 pp. We should also point out the recent publication of Vathek, a masterpiece of Gothicism originally written in French by William Beckford, an English romantic aristocrat. It has been edited and translated into Spanish by Javier Martín Lalanda (Madrid: Alianza Editorial, 1993), $384 \mathrm{pp}$.

Unrelated to the field of English studies, but indicative of the high standards of scholarship reached by English-speaking critics in the study of Spanish literature, are the monographs regularly published in London by Tamesis Books Limited. Among many others, we should mention Charles F. Fraker's Celestina: Genre and Rhetoric (London: Tamesis Books, 1990), 103 pp. 